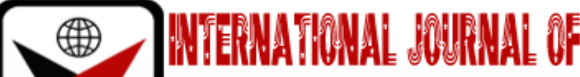

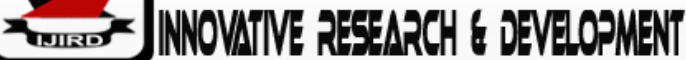

ISSN 2278 - 0211 (Online)

\section{Metacognitive Awareness and Knowledge Acquisition Approaches among Colleges of Education Students in Nigeria}

\begin{tabular}{|c|} 
Haruna, Mahmud Jikamshi \\
Chief Lecturer, Department of Educational Psychology, \\
Isa Kaita College of Education, Dutsinma, Nigeria \\
Bawa, Muhammad Dahiru \\
Principal Lecturer, Department of Mathematics, \\
Isa Kaita College of Education, Dutsinma, Nigeria \\
Lawal, Muntari \\
Senior Lecturer, Department of English, \\
Isa Kaita College of Education, Dutsinma, Nigeria \\
Abdullahi, Ibrahim Maikaita \\
Senior Lecturer, Department of Biology, \\
Isa Kaita College of Education, Dutsinma, Nigeria
\end{tabular}

\section{Abstract:}

Recently, scholars in education and psychology have been conducting various researches on how best college students acquire knowledge and academically succeed. This study examines the relationship between metacognitive awareness skills and the dimensions of knowledge acquisition approaches among pre-service teachers in Colleges of Education. In this quantitative study, a total of 500 pre-service teachers participated in the study comprising of, 280 males and 220 females, studying in Colleges of Education in North-West geo-political region of Nigeria. Descriptive statistics and Pearson correlation was employed for data analysis of the study. The descriptive result showed that majority of the pre-service teachers are employing surface knowledge acquisition approach and majority fall in the low level of metacognitive awareness skills. However, inferential statistics revealed a significant and positive relationship between metacognitive awareness, and deep knowledge acquisition approach, but a significant and negative relationship, with surface knowledge acquisition approach. Theoretical and practical implications of the study, as well as recommendations for future research, were presented as well.

Keywords: Knowledge acquisition, metacognitive awareness, pre-service teachers

\section{Introduction}

Recently, researchers in education and psychology have concluded that, the manner in which students approach their learning is an important determinant of educational attainment that needs attention to improve curriculum design and delivery. Scholars contended that since mid-1970s to date, there is an increasing focus by researchers in the area of students' metacognitive awareness from various fields, which includes but is not limited to the field of psychology, science, sports, health and education (Akyuzluer, 2014). It is the purpose of this paper to examine metacognitive awareness skills and knowledge acquisition approaches among pre-service teachers in some selected colleges of education in Nigeria.

\section{Metacognitive Awareness}

The concept of metacognition is a psychological construct that was first introduced in the area of education and psychology by Flavell (1979), who defined metacognition to mean 'individual's awareness of how he learns and what he does to gain his learning goals. By this definition metacognition is thus an activity that individual learners engaged into, that enables them to monitor and control their cognition. Another definition is that metacognition is the individual learner's cognitive processes and how he/she uses it to learn and remember (Ormrod, 2004). Thus, to some scholars, metacognition is both a process and a skill. As a skill, it is about self-awareness and strategic management of self. As a process, metacognition involves conscious, self-directed investigation of one's mental process.

Metacognition can be of great help in enhancing conceptual understanding of science (Colthorpe et al., 2018), also helps to develop students' higher-ordered thinking skills among learners (Ghanizadeh, 2017), and improve their attitude towards science in order to improve the students' learning outcomes in science (Jahangard et al., 2016). Metacognition has been the determining factor for students' success in solving problems (Balta et al., 2016). According to Haeruddin; 
Prasetyo, Zuhdan Kun; Supahar, (2020) the term metacognition is now included in the current curriculum of Indonesia Educational system.

Researchers conceptualize metacognitive awareness as having two major dimensions, thus; metacognitive knowledge and metacognitive regulation (Nietfeld, Cao \& Osborne, 2005; Schraw\& Dennison, 1994; Veenman, Van HoutWolters, \&Afflerbach, 2006; Veenman, Hesselink, Sleeuwaegen, Liem, \& Van Haaren, 2014). Metacognitive knowledge can be described as what we know about our own cognitive processes. Declarative, procedural, and conditional knowledge may all be considered sub-components of metacognitive knowledge (Schraw and Moshman, 1995). Metacognitive regulation means the actual activities in which we engage ourselves to facilitate our learning and memory, in other words the ways we regulate our cognitive processes, which includes; planning, monitoring, and evaluating (Schraw and Moshman, 1995). Metacognitive awareness enables students to transfer knowledge to new situations, while at the same time it makes a great impact in the students' acquisition of knowledge, comprehension, retention, and application of what was learned in the college, thus making students more efficient learners, critical thinkers, and problem solvers (Leat \& Lin, 2003; Mevarech, Terkieltaub, Vinberger, \&Nevet, 2010: Veloo. Rani. \& Hariharan, 2015). Therefore, by implication, if students have well-developed metacognitive awareness skill, and they apply their metacognitive awareness appropriately in college learning, they will excel academically. This was reported by numerous scholars that, student's metacognitive awareness is a serious predictor of students learning outcomes in colleges and other institutions of learning (Van der Stel, \&Veenman, 2008).

\section{Knowledge Acquisition}

According to Weller et al. (2013). Researchers in education and psychology have investigated the most appropriate students' knowledge acquisition approaches to learning in typical college or university settings to enhance student's general academic performances. Although these researches have been going on for several decades. Marton and Säljö, (1976) were however, the first two pioneers to introduce the concepts of deep and surface approaches to knowledge acquisition. In the contemporary cognitive psychology literature, Marton and Saljo, (1976) were also credited for introducing the two constructs that give a qualitative description of students' knowledge acquisition approaches in typical college or university setting. They conducted an empirical study on the qualitative differences of students' knowledge acquisition approaches, that ultimately led to the introduction of the two constructs (deep and surface knowledge acquisition approaches) (August-Brandy, 2004, Evans, 2002 and Jong, 1996). The terms 'deep-level processing' and 'surface- level processing' were used by Marton and Sa"ljo, to describe the way students approach particular knowledge acquisition tasks. These constructs were accepted, expanded, and instruments were developed to measure them by Entwistle, \& Ramsden (1982) and Biggs (1987) among others.

According to their findings, students adopting the deep approach to knowledge acquisition are willing to understand, and they are active in their studies. They interact critically with the arguments and evidence, they also try to relate ideas and look for patterns and principles using prior knowledge and other resources (Novogrodsky,2012). They consider knowledge acquisition as an internal process to them (Entwistle, McCune \& Walker, 2000). In contrast, students who prefer the surface knowledge acquisition approach tend to be more interested in memorizing the material without understanding it. Focuses on reproducing content aimlessly, thus lacking purpose of understanding and they use different forms of rote learning (McCune \& Enwistle, 2000). In this regard therefore, deep knowledge acquisition approach is more likely to result in a high level of understanding and effective learning, whereas surface approach is likely to lead to a low level of understanding and ineffective learning (Entwistle \& Ramsden, 1983).

\section{Research Objectives}

- To describe the levels of the dimensions of metacognitive awareness skills among pre-service teachers across selected Colleges of Education.

- To describe the levels of the dimensions of knowledge acquisition approaches among pre-service teachers across selected Colleges of Education

- To examine the relationships between metacognitive awareness and the dimensions of knowledge acquisition approaches (Deep \&Surface approaches) among pre-service teachers across selected Colleges of Education

\section{Research Questions and Hypotheses}

- What are the levels of the dimensions of metacognitive awareness among pre-service teachers?

- What are the levels of the dimensions of knowledge acquisition approaches among pre-service teachers?

To test the two hypotheses under the research objective inferential Statistical approach was employed.

- $\mathrm{H}_{01}$ : There is no significant relationship between metacognitive awareness and deep knowledge acquisition approaches among pre-service teachers across Colleges of Education

- $\mathrm{H}_{02}$ There is no significant relationship between metacognitive awareness and surface knowledge acquisition approaches among pre-service teachers across Colleges of Education

\section{Research Methodology and Design}

This study is a quantitative co-relational study, where a total of 500 pre-service teachers participated, comprising of, 280 males and 220 females, studying in 3 colleges of education, namely; Isa Kaita College of Education Dutsinma (IKCOE), Federal college of education Katsina (FCEK), and College of Education Gumel (COE Gumel). All these colleges are located in Nigeria. Persons' product moment coefficient of correlation was employed for data analysis in the study. All the 
participants are final year students for the Nigeria Certificate in Education (NCE) programme. A random sampling technique was used to collect data for the study.

The students were administered with a questionnaire containing instruments extracted from the following; Approaches to Study Skills Inventory for Students (ASSIST) developed by Entwistle et al. (2006) and Metacognitive Awareness Inventory (MAI) developed by Schraw and Dennison (1994). Prior permission was obtained from the original authors of the respective inventories. All participants were provided with a booklet containing a covering letter on instructions about their response to the questionnaire, the demographic questions, and the test items. The test consists of 28 items measuring students' metacognitive awareness, with 14 items measuring students 'cognition of knowledge and another 14 items measuring knowledge regulation. Students responded to the instruments during regular class lectures of Educational Psychology course, under the supervision of their respective course lecturers. All participants were assured that there were neither correct nor wrong answers, but were instructed to think about each question and answer it as it applied to them after which they were allowed to complete the questionnaire on their own within 45 minutes.

\section{Results}

The SPSS Statistical package version 22 for Windows was used for data analysis. This study has interesting and expected findings from the hypotheses tested. First, the descriptive statistics of the participants' levels on the variable under this study provided some insights into the characteristics of the pre-service teachers under study. The participants levels on the variables understudy were categorized in to 3 levels; low, moderate, and high. Therefore, based on these categorizations the result of the participants' levels on the variables understudy is presented in table 1 below which reveals that, majority which represents (59.0\%) of the pre-service teachers are employing surface knowledge acquisition approach in their study while in the college, this is a reasonable number compared to $(28.2 \%)$ who employed deep Knowledge acquisition approach. From the previous literature it is confirmed that, students do have preferences for either deep or surface approach to knowledge acquisition, though these differences are not fixed characteristics on a particular student; the choice of deep or surface approach, all depended on the teaching and learning context (Biggs, 1999). Also, the participants' level on metacognitive awareness indicates that majority representing (57.6\%) are in lower level, compared to $(28.4 \%)$ that are in the higher level, meaning that most of them are lacking higher level of metacognitive awareness skills.

\begin{tabular}{|c|c|c|c|c|c|c|c|c|c|c|}
\hline & \multicolumn{2}{|c|}{ Low } & \multicolumn{2}{c|}{ Moderate } & \multicolumn{2}{c|}{ High } & & & & \\
\hline Variables & $\mathbf{( N )}(\mathbf{0 )}$ & $\mathbf{( N )} \mathbf{( \% )}$ & $\mathbf{( N )} \mathbf{( \% )}$ & Mean & SD & Mini & Max \\
\hline DKA & 287 & 57.4 & 72 & 14.4 & 141 & 28.2 & 52.35 & 26.96 & 20 & 100 \\
\hline SKA & 70 & 14.0 & 155 & 27.0 & 295 & 59.0 & 55.56 & 21.34 & 16 & 80 \\
\hline MTC & 288 & 57.6 & 70 & 14.0 & 142 & 28.4 & 40.22 & 9.25 & 24 & 120 \\
\hline \multicolumn{8}{|c|}{ Table 1: Summary of Participants Levels on Knowledge Acquisition and }
\end{tabular}

Key: DKA = Deep Knowledge Acquisition; SKA = Surface Knowledge Acquisition; MTC = Metacognitive Awareness

\section{Statistical Analysis and Test of Hypotheses}

Data from the study was analyzed using Pearson product moment Coefficient of Correlation using SPSS. The result of the analysis is given in table 2 below.

\begin{tabular}{|c|c|c|c|c|}
\hline Variables & $\mathbf{Y}_{\mathbf{1}}$ & $\mathbf{Y}_{\mathbf{2}}$ & $\chi \mathbf{2}$ & \\
\hline $\mathrm{Y}_{1}$ Deep Knowledge Acquisition & 1 & & & \\
\hline $\mathrm{Y}_{2}$ Surface Knowledge Acquisition & $0.848^{*}$ & 1 & & \\
\hline$\chi_{2}$ Metacognitive Awareness & $0.452^{*}$ & $-0.204^{*}$ & $-0.169^{*}$ & 1 \\
\hline
\end{tabular}

Table 2: Correlation Matrix of (Deep \& Surface Knowledge Acquisition and Metacognitive Awareness ${ }^{*}$ Correlation Is Significant At the 0.05 Level (2-Tailed)

- $\mathrm{Ho}_{1}$ : There is no significant relationship between metacognitive awareness and deep knowledge acquisition approaches among pre-service teachers' in Nigeria.

- $\mathrm{Ho}_{2}$ : There is no significant relationship between metacognitive awareness and surface knowledge acquisition approaches among pre-service teachers across Colleges of Education

Table 2, below shows that, there is significant medium positive relationship between metacognitive awareness and deep knowledge acquisition approach $(\mathrm{r}=0.452, \mathrm{P}<0.01)$. This mandates a rejection of $\mathrm{Ho}_{1}$, and the conclusion that There is a significant $(\mathrm{P}<0.01)$ positive relationship $(\mathrm{r}=0.452)$ between metacognitive awareness and deep knowledge acquisition approaches among pre-service teachers' in Nigeria

The Table also reveals that, there is a significant low negative relationship between metacognitive awareness and surface knowledge acquisition approach $(\mathrm{r}=-0.204, \mathrm{P}<0.01)$. This mandates a rejection of $\mathrm{Ho}_{2}$ and the conclusion that There is a significant $(\mathrm{P}<0.01)$ negative relationship $(\mathrm{r}=-0.204)$ between metacognitive awareness and surface knowledge acquisition approaches among pre-service teachers across Colleges of Education in Nigeria. 


\section{Discussion}

Table 2 above shows that the relationship between metacognitive awareness, and deep and surface Knowledge acquisition approaches. This finding agrees with the theoretical expectations and previous literature (Batha and Carroll, 2007; Metallidou, 2008) that, good metacognitive awareness skills influence students learning positively. Metacognitive awareness refers to students' ability to understand and monitor their cognitive processes (Schraw, Crippen, \& Hartley, 2006). Metacognitive awareness is important in learning, and is often described as one of the stronger predictors of students' knowledge acquisition variable in the college (Dunning et al., 2003). Previous studies reveal that, metacognitive awareness help students to create a more better study habits and improve their performance and be able to evaluate their academic progress, and is related to deep knowledge acquisition approach (Järvelä, Järvenoja, 2011 and Zimmerman, 2008).

The result of the study showed that majority of the pre-service teachers employ surface knowledge acquisition approach in their study while in the college, therefore they tend to be surface learners. This agrees with what was reported in the literature that Students who adopted deep approaches to learning usually had long-term information retention, are cognitively active, are able to integrate information, and do also have high qualitative learning outcomes. In contrast to those students who take a surface approach who tend to have poor information retention, unable to integrate information thus, jumping through the necessary hoops in order to acquire the marks, or the grades, or the qualification (Duarte, 2007; Tynjälä, Salminen, Sutela, Nuutinen, \& Pitkänen, 2005; Veenman, Wilhelm, \& Beishuizen, 2004).

\section{Implication of this Study}

A significant theoretical implication of this study is that, majority of the pre-service teachers are employing surface knowledge acquisition approach in their study while in the college, thus they tend to be surface learners. According to the previous literature students who take a surface approach in their study tend to have poor information retention, are unable to integrate information thus are found jumping through the necessary hoops in order to acquire the passing grades. In the contrast students who adopts deep approaches to learning usually had long-term information retention, are cognitively sound, are able to integrate information, and finally tend to have high qualitative learning outcomes (Duarte, 2007; Tynjälä, Salminen, Sutela, Nuutinen, \& Pitkänen, 2005; Veenman, Wilhelm, \& Beishuizen, 2004).

The study also revealed a significant positive relationship between deep knowledge acquisition approach and metacognitive awareness and negative relationship between deep knowledge acquisition approach and metacognitive awareness. This suggests that students with low metacognitive skills often labelled with such terms as 'incompetent', because they perform inadequately compared to their peers with higher metacognitive awareness (Batha and Carroll, 2007) may benefit from metacognitive awareness training to improve their metacognitive awareness skills and knowledge acquisition strategies (Metallidou, 2008). Metacognition enables students to be strategic in their learning and study habits (Metallidou, 2008). There is thus the need for college lectures to correct these inappropriate study habits of their students.

Practically, it is very essential for pre-service teachers to possess and apply effective metacognitive awareness strategies while on training. If pre-service teachers make use of effective metacognitive awareness skills in the processes of acquiring knowledge while on training in the college, it is highly hoped that, they are going to provide their own students/pupils with similar higher quality learning skills (Senemoglu, 2011). Pre-service teachers in Nigeria, need to be educated and encouraged by their college lectures to develop metacognitive skills. In line with this idea, it is necessary to help pre-service teachers to plan, monitor, evaluate, and revise their cognitive progress, as this will lead them to a wide variety of metacognitive experiences in their college learning. Such strategy may also include attempting to enhance students' selection of appropriate goal orientation strategy that may enhance students' knowledge acquisition approach in typical college setting. This will reduce students overstay in colleges and thus less economic costs to their parents. More research needs to be conducted on how best pre-service teachers can develop metacognitive awareness skills that will help them to understand their learning problems and employ relevant strategies to overcome them, so that they can succeed academically in the college.

These findings of the study revealed significant information to the area of research in education and psychology, and the field of students' metacognitive awareness in relation to student's knowledge acquisition approaches. Theoretically, this study contributes to the literature, and studies in knowledge acquisition approaches by relating metacognitive awareness and the dimensions of knowledge acquisition approaches.

\section{Recommendations}

There is need for a further detailed research in to this area. One of the practical implications for this study is that, pre-service teachers in Nigeria, need to be educated and encouraged by their college lectures to develop, metacognitive awareness skills as this will greatly help them to acquire meaningful knowledge or deep knowledge acquisition. In line with this idea, it is necessary to help pre-service teachers to plan, monitor, evaluate, and revise their cognitive progress, as this will lead them to a wide variety of motivational and cognitive experiences in their college learning.

\section{References}

i. Akyüzlüer, F, (2014). Metacognition Skills of Pre-service Music Teachers. International Periodical for the Languages, Literature and History of Turkish or Turkic. Volume 9/8, p. 187-196,

ii. August-Brandy. M, (2005). The effect of metacognitive intervention on approach to Self-regulation of learning in Baccalaureate nursing students, Journal of nursing Education, vol. 44, No.70

iii. Batha, K., \& Carroll, M. (2007). Metacognitive training aids decision making. Australian Journal of Psychology, 59(2), 64-69. 
iv. Biggs, J.B. (1987). Student approaches to learning. Melbourne: Australian Council for Educational Research.

v. Colthorpe, K., Sharifirad, T., Ainscough, L., Anderson, S., \& Zimbardi, K. (2018). Prompting undergraduate students' metacognition of learning: implementing 'meta-learning' assessment tasks in the biomedical sciences. Assessment \& Evaluation in Higher Education, 43(2), 272-285.

https://doi.org/10.1080/02602938.2017.1334872

vi. Duarte, A. M. (2007). Conceptions of learning and approaches to learning in Portuguese students. Higher Education, 54(6), 781-794.

vii. Dunning, D., Johnson, K., Ehrlinger, J., \& Kruger, J. (2003). Why people fail to recognize their own incompetence. Current Directions in Psychological Science, 12(3), 83-87

viii. Entwistle, N. J., \& Ramsden, P. (1983). Understanding Student Learning. London: Croom Helm

ix. Entwistle, N. J., McCune, V., \& Walker, P. (2000). Conceptions, styles, and approaches within higher education: analytic abstraction and everyday experience. In R. J. Sternberg L-F. Zhang (Eds.) Perspective on Cognitive, Learning, and Thinking Styles. Mahwah, N. J.: Lawrence Erlbaum.

X. Entwistle, N., McCune, V., \& Tait, H. (2006). Approaches and Study Skills Inventory for Students (ASSIST): Report of the development and use of the inventory. Unpublished Report received from N. Entwistle

xi. Enwistle, N. J. (2000). Approaches to studying and levels of understanding: The Influences of teaching and assessment In J. C. Smart (ed.), Higher Education: Handbook of Theory and Research (Vol. XV), (pp. 156-218). New York: Agathon Press.

xii. Evans. E, et al., (2002). Gender difference in Interest and knowledge Acquisition: The United States, Taiwan, and Japan, Journal of sex roles, Vol47, No.314,

xiii. Flavell, J.H. (1979). Metacognition and cognitive monitoring: A new area of cognitive- developmental inquiry. American Psychologist, 34, 906-911.

xiv. Ghanizadeh, A. (2017). The interplay between reflective thinking, critical thinking, self-monitoring, and academic achievement in higher education. Higher Education, 74(1), 101-114. https://doi.org/10.1007/s10734-016-0031-y

xv. Haeruddin; Prasetyo, Zuhdan Kun; Supahar, (2020). The Development of a Metacognition Instrument for College Students to Solve Physics Problems, International Journal of Instruction. Vol. 13 Issue 1, p767-7

xvi. Jong. T, et al., (1996) Types and Qualities of knowledge Education Psychologist, 31(2) 105-113

xvii. Jahangard, Z., Soltani, A., \& Alinejad, M. (2016). Exploring the relationship between metacognition and attitudes towards science of senior secondary students through a structural equation modelling analysis. J. of Baltic Science Education, 15(3), 340-349.

xviii. Leat, D., \& Lin, M. (2003). Developing a pedagogy of metacognition and transfer: Some signposts for the generation and use of knowledge and the creation of research partnerships. British Educational Research Journal, 29(3), 383-415.

xix. Marton, F., \& Säljö, R. (1976). On qualitative differences in learning: I - Outcome and process. British Journal of Educational Psychology, 46, pp. 4-11.

xx. Metallidou, P., \& Platsidou, M. (2008). Kolb's Learning Style Inventory-1985: Validity issues and relations with metacognitive knowledge about problem-solving strategies. Learning and Individual Differences, 18(1), 114119.

xxi. Mevarech, Z., Terkieltaub, S., Vinberger, T., \& Nevet, V. (2010). The effects of metacognitive instruction on third and sixth graders solving word problems. ZDM Mathematics Education, 42, 195-203.

xxii. Nietfeld, J. L., Cao, L., and Osborne J. W. (2005). Metacognitive monitoring accuracy and student performance in the postsecondary classroom. The Journal of Experimental Education, 74(1), 7-28.

xxiii. Novogrodsky, D, (2012). Analysis of learning styles of diverse students' populations, and Implications for higher education instructional change, PhD. Dissertation, Submitted to School of Education, St. John's University USA

xxiv. Ormrod, J.E. (2004). Human Learning. Upper Saddle River, NJ: Pearson Prentice Hall

xxv. Schraw, G. and Dennison, R. S. (1994). Assessing metacognitive awareness. Contemporary Educational Psychology, 19, 460-475.

xxvi. Schraw, G. and Moshman, D. (1995). Metacognitive Theories. Educational Psychology Review, 7(4), $351-371$.

xxvii. Schraw, G., \& Dennison, R.S. (1994). Assessing metacognitive awareness. Contemporary Educational Psychology, 19, 460-475.

xxviii. Schraw, G., Crippen, K. J., \& Hartley, K. (2006). Promoting self-regulation in science education: Metacognition as part of a broader perspective on learning. Research in Science Education, 36(1-2), 111-139.

xxix. Senemoglu, N. (2011). College of Education students' approaches to learning and study skills. Egitim ve Bilim, 36(160), 65.

xxx. Tynjälä, P., \& Salminen, R. T., Sutela, T., Nuutinen, A. \& Pitkänen, S. (2005). Factors related to study success in technology education. European Journal of Engineering Education, 30(2), 221-231

xxxi. Van der Stel, M., \& Veenman, M. V. J. (2008). Relation between intellectual ability and metacognitive skillfulness as predictors of learning performance of young students performing tasks in different domains. Learning \& Individual Differences, 18(1), 128-134.

xxxii. Veenman, M. V. J., Van Hout-Wolters, B. H. A. M., \& Afflerbach, P. (2006). Metacognition and learning: conceptual and methodological considerations. Metacognition and Learning, 1, 3-14. 
xxxiii. Veenman, M. V. J., Wilhelm, P., \& Beishuizen, J. J. (2004). The relation between intellectual and metacognitive skills from a developmental perspective. Learning and Instruction, 14, 89-109.

xxxiv. Veenman.M.V. J, Hesselink. R. D, Sleeuwaegen. S, Liem. S. I. E \& Van Haaren. M.G.P, (2014). Assessing Developmental Differences inMetacognitive Skills with Computer Logfiles: Gender by Age Interactions. Psychological Topics 23, 1, 99-113.

xxxv. Veloo. A, Rani. M. A., \& Hariharan. K, (2015).The Role of Gender in the Use of Metacognitive Awareness Reading Strategies among Biology Students. Asian Social Science; Vol. 11, No. 1; Published by Canadian Center of Science and Education

xxxvi. Wang, M. C., Haertel, G. D., \& Walberg, H. J. (1990). What influences learning? A content analysis of review literature. Journal of Educational Research, 84, 30-43.

xxxvii. Weller. J. M, Henning. M, Civil. N, La very. L \& Boyd. M. J Jolly. B, (2013). Approaches to learning for the ANZCA Final Examination and validation of the revised Study Process Questionnaire in specialist medical training. Anaesth Intensive Care; VOL. 41 No. 5,631-640

xxxviii. Wolters, C.A., \& Pintrich, P.R. (1998). Contextual differences in student motivation and self-regulated learning in mathematics, English, and social-studies classrooms. Instructional Science, 26, 27-47.

xxxix. Young, A. and Fry, J.D, (2008). Metacognitive awareness and academic achievement in mcollege students Journal of the Scholarship of Teaching and Learning, Vol. 8, No. 2, pp. 1-10.

xl. Yunus, D. \&Murat, T., (2017). Effect of Metacognitive Awareness on Achievement in Foreign Language Learning. Istanbul University ticaret tesi sosyal bilimler dergisi 16 (31)297-310

xli. Zimmerman, B. J. (2008). Investigating self-regulation and motivation: Historical background, methodological developments, and future prospects. American Educational Research Journal, 45(1), 166-183. 